\title{
Oceanicola granulosus gen. nov., sp. nov. and Oceanicola batsensis sp. nov., poly- $\beta$-hydroxybutyrate-producing marine bacteria in the order 'Rhodobacterales'
}

Correspondence

Stephen J. Giovannoni

steve.giovannoni@orst.edu

\section{INTRODUCTION}

The Roseobacter clade (synonym 'Roseobacter-SulfitobacterSilicibacter' group; Wagner-Döbler et al., 2003) in the order 'Rhodobacterales' (Garrity \& Holt, 2001), which was named after the genus Roseobacter by Giovannoni \& Rappé (2000), is the second most abundant $16 \mathrm{~S}$ rRNA gene clone type in marine environments (Rappé et al., 2000; Giovannoni \& Rappé, 2000). This bacterial group is relatively readily cultivable compared to more common marine bacterial lineages such as SAR11, SAR116, SAR86, SAR202 and marine Actinobacteria. In the last few years, a large number of strains from this group have been isolated from diverse marine environments (Connon \& Giovannoni, 2002;

Published online ahead of print on 9 January 2004 as DOI 10.1099/ ijs.0.3015-0.

Abbreviations: BATS, Bermuda Atlantic Time-series Study; PHB, poly$\beta$-hydroxybutyrate.

The GenBank accession numbers for the 16S rRNA gene sequences of strains HTCC2516 ${ }^{\top}$, HTCC2523 and HTCC2597 ${ }^{\top}$ are AY424896, AY424897 and AY424898, respectively.
Allgaier et al., 2003), and many have been identified as novel genera and species (Doronina et al., 2000; Labrenz et al., 2000; Urbance et al., 2001; Schaefer et al., 2002). This group is currently comprised 11 chemoheterotrophic genera, Antarctobacter (Labrenz et al., 1998), Sagittula (González et al., 1997), Ruegeria (Uchino et al., 1998), Silicibacter (Petursdottir \& Kristjansson, 1997), Leisingera (Schaefer et al., 2002), Sulfitobacter (Sorokin, 1995), Octadecabacter (Gosink et al., 1997), Jannaschia (WagnerDöbler et al., 2003), Ketogulonicigenium (Urbance et al., 2001), 'Marinosulfonomonas' (Holmes et al., 1997) and Methylarcula (Doronina et al., 2000), and four bacteriochlorophyll $a$-containing genera, Roseobacter (Shiba, 1991), Roseovarius (Labrenz et al., 1999), Staleya (Labrenz et al., 2000) and Roseovivax (Suzuki et al., 1999). The metabolism of isolates in this bacterial group has been reported to be very diverse, including such metabolic pathways as aerobic anoxygenic photosynthesis (Shiba, 1991; Allgaier et al., 2003), oxidation or degradation of sulfite (Sorokin, 1995; Pukall et al., 1999), methanesulfonic acid (Holmes et al., 1997), dimethylsulfoniopropionate (Ledyard et al., 
1993; González et al., 2000, 2003), methylamine (Doronina et al., 2000), methyl bromide (Schaefer et al., 2002), lignin (González et al., 1997), aromatic compounds (Buchan et al., 2000) and production of allelopathic compounds (Lafay et al., 1995), suggesting that they play an important role for oceanic nutrient cycling.

In this study, three strains were isolated from the Bermuda Atlantic Time-series Study (BATS) site using the highthroughput culturing method. Polyphasic analyses indicated that these isolates represent a novel genus within the Roseobacter clade of the order 'Rhodobacterales'. Two new species, Oceanicola granulosus sp. nov. and Oceanicola batsensis sp. nov., in a new genus Oceanicola gen. nov.

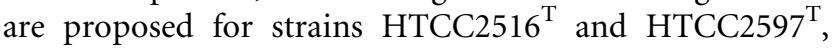
respectively.

\section{METHODS}

Isolation. Collecting sea water samples at BATS, Sargasso Sea, Atlantic Ocean and high-throughput culturing were performed as described previously (Cho \& Giovannoni, 2003b). The liquid cultures of three strains designated HTCC2516 ${ }^{\mathrm{T}}$, HTCC2523 and HTCC $2597^{\mathrm{T}}$ were obtained after incubating dilution-to-extinction cultures for $21 \mathrm{~d}$ at $16^{\circ} \mathrm{C}$. These liquid cultures were spread and purified as single colonies on marine agar 2216 (Difco) after incubation for 10 days at $30^{\circ} \mathrm{C}$.

Microscopy. The strains were grown to late exponential phase in marine broth 2216 (Difco) at $30^{\circ} \mathrm{C}$ and 150 r.p.m. on a rotatory shaker. Cell size and cell morphology were examined by both Safranin O-stained light microscopy and DAPI $\left(4^{\prime}, 6\right.$-diamidino-2phenylindole; Porter \& Feig, 1980)-stained epifluorescence microscopy, under a Leica DMRB microscope equipped with a cooled CCD camera (ORCA-ER; Hamamatsu) and IPLab v3.5 scientific imaging software (Scanalytics). Motility was examined from wet mounts of exponential-phase cells under dark-field microscopy (DMRB; Leica). Accumulation of poly- $\beta$-hydroxybutyrate (PHB) was determined by the Sudan Black staining method (Smibert \& Krieg, 1994) under a Leica light microscope. Negatively stained transmission electron micrographs were taken as described elsewhere (Cho \& Giovannoni, 2003b).

Phenotypic characterization. Tests used for phenotypic characterizations have been detailed in previous studies (Cho \& Giovannoni, 2003a, b). The following biochemical and phenotypic characteristics were examined: morphology of cells and colonies; Gram staining; motility; cell pigmentation; bacteriochlorophyll $a$; ranges and optima for temperature, $\mathrm{pH}$ and salinity; oxidase and catalase production; glucose acidification; arginine dihydrolase; $\beta$-galactosidase activity; denitrification; indole production; hydrolysis of urea, arginine and aesculin; accumulation of PHB; sodium requirement; utilization of sole carbon sources (47 carbon compounds); oxidation of carbon sources (SN2; Biolog); and susceptibility to antibiotics (14 antibiotics).

Chemotaxonomy. Cellular fatty acid methyl esters were prepared and analysed using gas chromatography according to the instructions of the Microbial Identification System (MIDI). Fatty acid profiles were analysed by Microbial ID. Genomic DNA was extracted and purified using the Qiagen DNeasy tissue kit. The DNA G+C contents were analysed by HPLC according to Mesbah et al. (1989) using a Platinum EPS reverse-phase C18 column $(150 \mathrm{~mm}, 4.6 \mathrm{~mm}$, $5 \mu \mathrm{m}$ pore size; Alltech). Phage $\lambda$ DNA was used as standards throughout the analyses.
DNA-DNA hybridization. Percentages of genomic DNA relatedness among the HTCC strains were determined by dot-blot hybridizations. Probe DNA of strain HTCC $2516^{\mathrm{T}}$ was prepared using DIG High prime DNA labelling and detection starter kit I (Roche Molecular Biochemicals). Genomic DNAs from strains HTCC $2516^{\mathrm{T}}$, HTCC2523 and HTCC $2597^{\mathrm{T}}$ were denatured by boiling for $10 \mathrm{~min}$ in $6 \times$ SSC $(1 \times$ SSC: $0 \cdot 15 \mathrm{M} \mathrm{NaCl}, 0 \cdot 015 \mathrm{M}$ sodium citrate $)$ and transferred onto positively charged nylon membranes by UV crosslinking. Prehybridization, hybridization, stringency washing and detection were performed according to the manufacturer's instructions. The hybridization temperature was $52^{\circ} \mathrm{C}$ and stringency washing was carried out in $0.5 \times$ SSC and $0.1 \%$ SDS at $65^{\circ} \mathrm{C}$ in a hybridization chamber. Densitometric analyses were carried out using the Personal Densitometer with ImageQuant imaging software (Amersham Biosciences).

Phylogenetic analyses. The $16 \mathrm{~S}$ rRNA gene fragments of the marine strains were generated by PCR as described previously (Cho \& Giovannoni, 2003b) and directly sequenced by the chaintermination method on an ABI 377 automated sequencer. Nearly full-length sequences of the 16S rRNA gene were aligned against a variety of other $16 \mathrm{~S}$ rRNA gene sequences using the ARB software package (Ludwig et al., 1998) and 1186 unambiguously aligned nucleotide positions were used for phylogenetic analyses in PAUP* 4.0 beta 10 (Swofford, 2002). Percentage sequence similarities were determined from distance matrices according to Jukes \& Cantor (1969). Phylogenetic trees were inferred by three different algorithms: neighbour-joining with Kimura two-parameter model; maximum-parsimony with a heuristic search; and maximumlikelihood with a heuristic search, TBR-branching, and a Ti/Tv ratio that was estimated from the dataset $(1 \cdot 395)$. The tree topologies from neighbour-joining and maximum-parsimony were evaluated by bootstrap analyses based on 1000 resamplings.

\section{RESULTS AND DISCUSSION}

\section{Cell and colony morphology}

All isolates were Gram-negative (by Gram staining and $\mathrm{KOH}$ test), non-motile short rods, $0 \cdot 7-2 \cdot 1 \mu \mathrm{m}$ long and $0 \cdot 4-1 \cdot 1 \mu \mathrm{m}$ wide, dividing by binary fission (Fig. 1). The cell length and width of strain HTCC2597 ${ }^{\mathrm{T}}$ were smaller than those of strains HTCC2516 ${ }^{\mathrm{T}}$ and HTCC2523. PHB granules were always detected in the three HTCC strains by both negatively stained electron microscopy (Fig. 1) and Sudan Black staining. The typical morphology of Gramnegative cell membranes was observed in electron micrographs. Neither flagella nor endospores were observed on negatively stained cells. Colonies were faint yellow, $0 \cdot 5-$ $1.5 \mathrm{~mm}$ in diameter, uniformly circular, convex and opaque after growth on marine agar 2216 at $30^{\circ} \mathrm{C}$ for $5 \mathrm{~d}$.

\section{Growth and physiological characteristics}

No isolates grew under strict anaerobic conditions, even with prolonged incubations of 30 days. However, strains HTCC $2516^{\mathrm{T}}$ and HTCC2523 sustained their growth activity under microaerobic conditions, although their growth was poor. The temperature range for growth was $4-40{ }^{\circ} \mathrm{C}$ (optimum $28-30^{\circ} \mathrm{C}$ ). The $\mathrm{pH}$ range for growth was $\mathrm{pH} 5 \cdot 5-$ $9 \cdot 5$ (optimum $7 \cdot 5-8 \cdot 0$ ) and the $\mathrm{NaCl}$ concentrations for growth were $0 \cdot 25-10 \%(\mathrm{w} / \mathrm{v})$ (optimum $2 \cdot 5-3 \cdot 0 \%)$. The 


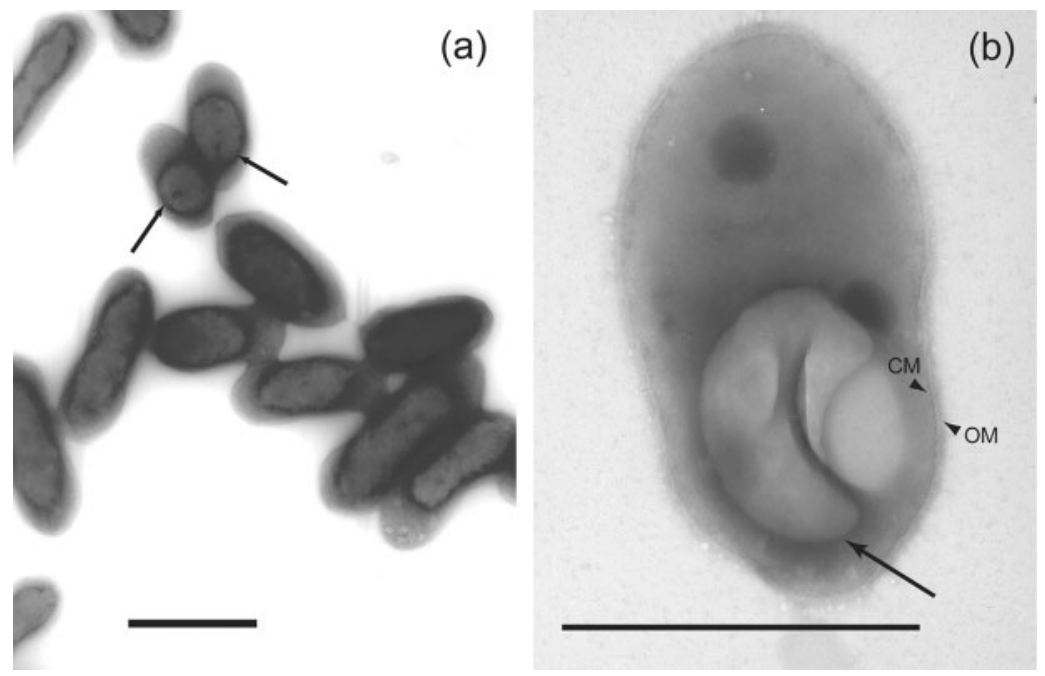

Fig. 1. Electron micrographs of negatively stained cells of strains HTCC2516 ${ }^{\top}$ (a) and $\mathrm{HTCC}_{2597^{\top}}$ (b). Arrows indicate PHB granules. OM, outer membrane; CM, cytoplasmic membrane. Scale bars, $1 \cdot 0 \mu \mathrm{m}$.

minimum $\mathrm{NaCl}$ concentrations for supporting growth were $0 \cdot 25 \%$ in HTCC2516 and $0 \cdot 75 \%$ in HTCC 2597 .

All HTCC isolates were oxidase-positive. Biochemical tests for denitrification activity, arginine and gelatin hydrolysis, indole production and glucose acidification were negative in all the HTCC isolates studied. The strains produced neither acetone/methanol-extractable pigments nor bacteriochlorophyll $a$. Therefore, the energy metabolism of the isolates appears to be exclusively non-photosynthetic chemoheterotrophy. Major characteristics that differentiate the strains are represented in Table 1. Biochemical characteristics, carbon source utilization patterns and antibiotic susceptibility clearly differentiated the strains from each other. The strains utilized a wide range of substrates, including hexoses, oligosaccharides, organic acids and amino acids as their sole carbon sources (custom-made 48-well plate tests). All three strains utilized D-galactose, D-maltose, D-melezitose, citric acid, formic acid, propionic acid, L-glutamic acid, L-serine and L-arginine as sole carbon sources. However, none of the strains utilized DL-glyceraldehyde, D-xylose, D-fructose, L-rhamnose, D-melibiose, D-raffinose, D-sorbitol, adonitol, ethanol, glycerol, methanol, succinic acid, itaconic acid, D-malic acid, L-ornithine, L-proline, L-lysine, D-mannose, Dglucosamine, L-leucine or L-isoleucine. All strains were susceptible to kanamycin, carbenicillin, tetracycline, ampicillin, puromycin, vancomycin, rifampicin and benzylpenicillin, and were resistant to nalidixic acid and cycloheximide.

\section{Phylogenetic analyses}

Nearly complete 16S rRNA gene sequences (1418-1423 bp) were determined for three HTCC isolates and used for phylogenetic analyses. Strains HTCC $2516^{\mathrm{T}}$ and HTCC2523 shared $99.9 \%$ sequence similarity, and represented $95 \cdot 1$ and $95.3 \%$ similarity to $\mathrm{HTCC} 2597^{\mathrm{T}}$, respectively. According
Table 1. Differential characteristics for the HTCC isolates studied

Strains: 1, Oceanicola granulosus $\mathrm{HTCC}_{2516^{\mathrm{T}}}$; 2, Oceanicola granulosus HTCC2523; 3, Oceanicola batsensis HTCC2597 ${ }^{\mathrm{T}}$.

\begin{tabular}{|c|c|c|c|}
\hline Characteristic & 1 & 2 & 3 \\
\hline Catalase & - & - & + \\
\hline Urease & - & - & + \\
\hline Aesculin hydrolysis & + & + & - \\
\hline$\beta$-Galactosidase & + & + & - \\
\hline \multicolumn{4}{|l|}{ Susceptibility to: } \\
\hline Chloramphenicol & + & + & - \\
\hline Streptomycin & - & + & + \\
\hline Erythromycin & + & - & + \\
\hline Gentamicin & - & - & + \\
\hline \multicolumn{4}{|l|}{ Sole carbon source utilization } \\
\hline D-Ribose & + & + & - \\
\hline D-Arabinose & - & - & + \\
\hline D-Glucose & + & + & - \\
\hline L-Sorbose & - & - & + \\
\hline Sucrose & + & + & - \\
\hline$\beta$-Lactose & + & - & - \\
\hline D-Trehalose & + & + & - \\
\hline D-Cellobiose & + & + & - \\
\hline D-Mannitol & - & - & + \\
\hline$N$-Acetyl-D-glucosamine & + & + & - \\
\hline Pyruvic acid & + & + & - \\
\hline Gluconic acid & + & - & + \\
\hline Malonic acid & - & - & + \\
\hline Lactic acid & - & + & + \\
\hline$m$-Inositol & - & + & + \\
\hline L-Alanine & + & + & - \\
\hline Glycine & - & - & + \\
\hline DNA G + C mol\% & $71 \cdot 5$ & $70 \cdot 9$ & $67 \cdot 3$ \\
\hline $\begin{array}{l}\text { DNA-DNA hybridization } \\
\text { (with HTCC } 2516^{\mathrm{T}} \text { ) }\end{array}$ & 100 & $95 \cdot 7$ & $48 \cdot 0$ \\
\hline
\end{tabular}




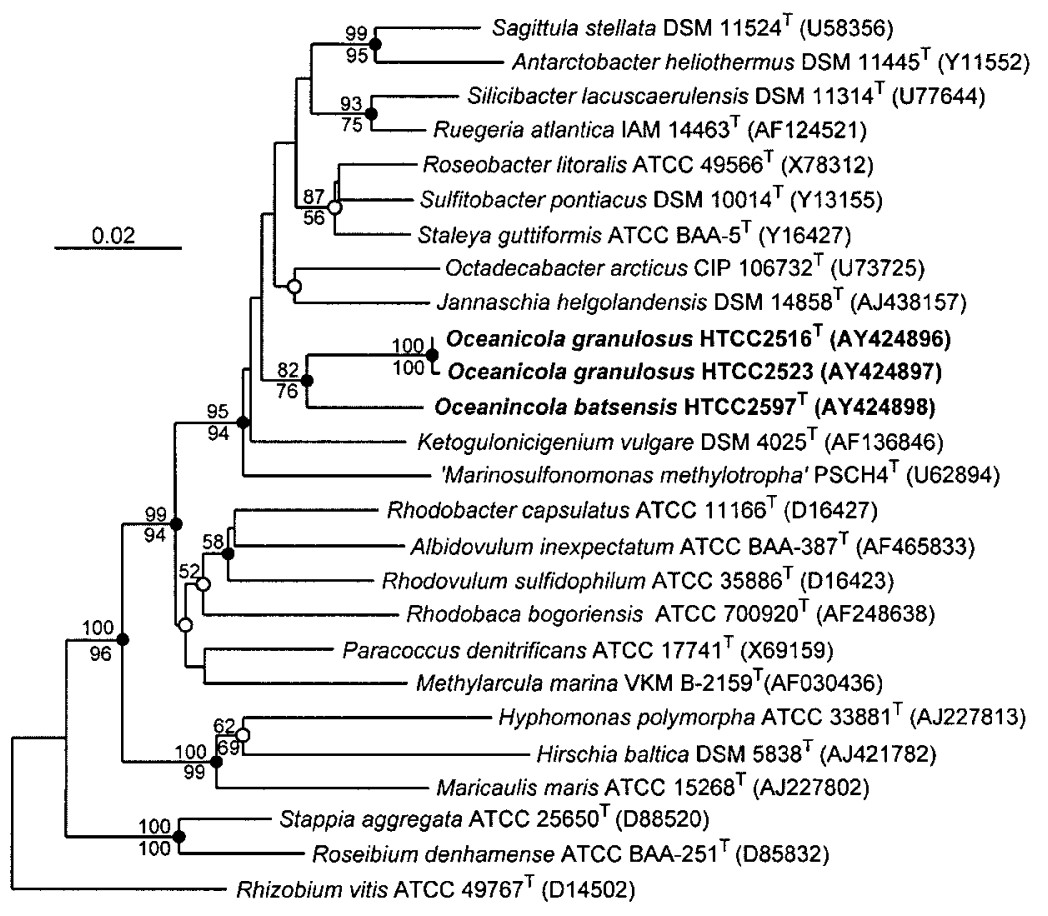

Fig. 2. Neighbour-joining tree showing relationships between the three HTCC isolates and representatives of the order 'Rhodobacterales' within the Alphaproteobacteria inferred from 16S rRNA gene sequence analyses. Bootstrap proportions over $50 \%$ from both neighbour-joining (above nodes) and maximum-parsimony (below nodes) are shown. The filled and open circles at each node indicate the nodes recovered reproducibly by all treeing methods and two treeing methods, respectively. Rhizobium vitis ATCC $49767^{\top}$ in the order 'Rhizobiales' was used as an outgroup to define the root of the tree. Scale bar, 0.02 substitutions per nucleotide position. to the practical $3 \%$ cut-off value for $16 \mathrm{~S}$ rRNA divergence to demarcate species (Stackebrandt \& Göebel, 1994), HTCC $2516^{\mathrm{T}}$ and $\mathrm{HTCC} 2597^{\mathrm{T}}$ represent two separate species. BLAST search results and phylogenetic analyses in the ARB database indicated that all strains belong to the order 'Rhodobacterales' of the Alphaproteobacteria. Sequence comparisons to validly named bacteria indicated that the three strains were most closely related to species recently classified, Ketogulonicigenium vulgarae (92-94\%), Jannaschia helgolandensis (92-93\%) and Octadecabacter arcticus (92-93\%). Strain HTCC2597 ${ }^{\mathrm{T}}$ was most closely related to Sargasso Sea isolate GMDsbM4 (GenBank no. AY162095; Zengler et al., 2002) with $99 \%$ similarity. In all phylogenetic trees, two strains represented by HTCC $2516^{\mathrm{T}}$ formed one distinct subclade with $100 \%$ bootstrap value and strain HTCC $2597^{\mathrm{T}}$ formed a separate branch (Fig. 2). The three HTCC isolates always formed a distant monophyletic clade with $76-82 \%$ bootstrap support for a position within the order 'Rhodobacterales' in different phylogenetic trees, and this clade was not closely associated with any other taxa in the order 'Rhodobacterales' (Fig. 2). These phylogenetic analyses indicated that the HTCC isolates represent a novel genus-level lineage within the Roseobacter clade of the order 'Rhodobacterales'.

\section{DNA relatedness and chemotaxonomy}

The DNA G + C content of the HTCC strains ranged from $67 \cdot 3$ to $71 \cdot 5 \mathrm{~mol} \%$ (Table 1 ). The $\mathrm{G}+\mathrm{C}$ content of strain ${\text { HTCC } 2597^{\mathrm{T}}}^{\mathrm{T}}$ was 3-4 mol\% lower than that of the other two strains. When the DNA of strain HTCC $2516^{\mathrm{T}}$ was used as a probe for DNA-DNA hybridization, strain HTCC2523 showed $95 \cdot 7 \%$ DNA relatedness to strain HTCC $2516^{\mathrm{T}}$, while strain $\mathrm{HTCC} 2597^{\mathrm{T}}$ showed $48 \cdot 0 \%$ relatedness (Table 1). From the results of $\mathrm{G}+\mathrm{C}$ mol\% and DNADNA hybridization analyses, the strains were clearly categorized into two genospecies. The predominant fatty acids in the isolates were $18: 1 \omega 7 c$, cyclo $19: 0,16: 0$ and methyl 18:1 (Table 2). The type strains HTCC $2516^{\mathrm{T}}$ and HTCC $2597^{\mathrm{T}}$ of the two genospecies were differentiated by the presence or absence of several fatty acids, including $12: 0,12: 1 \omega 11 c, 14: 0,15: 0$ and methyl $18: 1$, and by the proportions of $16: 0,18: 1 \omega 7 c$ and $19: 0$ cyclo $\omega 8 c$. The fatty acid profile of the HTCC isolates differed significantly from the phylogenetically related taxa in the order 'Rhodobacterales' mainly by the proportions of $16: 0$,

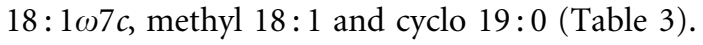

\section{Taxonomic conclusions}

Polyphasic approaches, including phenotypic data (Table 1), fatty acid profiles (Table 2), DNA G $+\mathrm{C}$ content (Table 1 ), DNA-DNA hybridization (Table 1) and 16S rDNA phylogenetic analyses (Fig. 2) support the placement of the HTCC isolates in a novel genus within the order 'Rhodobacterales' and comprise two distinct species. Furthermore, comparisons of phenotypic and biochemical characteristics among the phylogenetically associated genera and species clearly demonstrated that the isolates are not closely related to any of the previously described related taxa (Table 3). Two strains, HTCC2516 ${ }^{\mathrm{T}}$ and HTCC2523, shared very similar phenotypic and genotypic characteristics, such as $>99 \%$ $16 \mathrm{~S}$ rDNA sequence similarity and $>95 \%$ DNA-DNA hybridization, so they were regarded as members of the same species. Relatively low $16 \mathrm{~S}$ rDNA sequence similarity $(95 \%)$ and DNA relatedness (48\%) between strains 
Table 2. Cellular fatty acid composition (\%) of Oceanicola granulosus and Oceanicola batsensis

Strains: 1, Oceanicola granulosus HTCC2516 ${ }^{\mathrm{T}}$; 2, Oceanicola granulosus HTCC2523; 3, Oceanicola batsensis HTCC2597 .

\begin{tabular}{|lccc|}
\hline Fatty acid & $\mathbf{1}$ & $\mathbf{2}$ & $\mathbf{3}$ \\
\hline $10: 0$ & $0 \cdot 1$ & $0 \cdot 1$ & - \\
3 -OH $10: 0$ & $1 \cdot 5$ & $1 \cdot 6$ & $0 \cdot 4$ \\
$12: 0$ & - & - & $2 \cdot 0$ \\
$3-\mathrm{OH} 12: 0$ & $1 \cdot 6$ & $1 \cdot 9$ & - \\
$12: 1 \omega 11 c$ & - & - & $4 \cdot 9$ \\
$14: 0$ & - & - & $1 \cdot 5$ \\
$15: 0$ & - & - & $0 \cdot 9$ \\
$16: 0$ & $11 \cdot 9$ & $13 \cdot 2$ & $15 \cdot 0$ \\
iso $16: 0$ & - & $0 \cdot 3$ & - \\
$17: 0$ & $0 \cdot 4$ & $0 \cdot 2$ & $1 \cdot 5$ \\
anteiso $17: 0$ & $0 \cdot 2$ & $0 \cdot 3$ & - \\
cyclo $17: 0$ & $0 \cdot 2$ & $0 \cdot 6$ & - \\
$17: 1 \omega 8 c$ & $0 \cdot 3$ & - & - \\
$18: 0$ & $0 \cdot 9$ & $0 \cdot 9$ & $2 \cdot 4$ \\
$18: 1 \omega 7 c$ & $62 \cdot 8$ & $55 \cdot 4$ & $31 \cdot 0$ \\
Methyl $18: 1$ & $8 \cdot 1$ & $10 \cdot 9$ & - \\
cyclo $19: 0$ & $10 \cdot 8$ & $13 \cdot 1$ & $40 \cdot 4$ \\
$20: 2 \omega 6, \omega 9 c$ & - & $0 \cdot 4$ & - \\
$15: 0$ iso $2-\mathrm{OH}+16: 1 \omega 7 c$ & $1 \cdot 2$ & $1 \cdot 1$ & - \\
Total & $100 \cdot 0$ & $100 \cdot 0$ & $100 \cdot 0$ \\
& & & \\
\hline
\end{tabular}

HTCC2516 ${ }^{\mathrm{T}}$ and HTCC2597 ${ }^{\mathrm{T}}$ differentiated the strains into independent species (Wayne et al., 1987). The $4 \cdot 2 \mathrm{~mol} \%$ $\mathrm{G}+\mathrm{C}$ difference between strains HTCC2516 $^{\mathrm{T}}$ and HTCC2597 ${ }^{\mathrm{T}}$ supported the conclusion that both strains belong to the same genus, because a $10 \%$ difference in $\mathrm{G}+\mathrm{C} \mathrm{mol} \%$ is generally a criterion for differentiating genera (Stackebrandt \& Liesack, 1993). Therefore, we placed these type strains as two separate species in the same genus. Consequently, on the basis of both phylogenetic and phenotypic distinction, we propose the Oceanicola gen. nov., containing the species Oceanicola granulosus sp. nov. and Oceanicola batsensis sp. nov.

\section{Description of Oceanicola gen. nov.}

Oceanicola (o.ce.a.ni' co.la. L. n. oceanus the ocean; L. masc. suffix -cola inhabitant; N.L. masc. n. Oceanicola inhabitant of the ocean).

Cells are Gram-negative, non-motile short rods that multiply by binary fission. Accumulate PHB granules. Neither flagella nor endospores were observed. Faint yellowish colonies are formed on marine agar. Bacteriochlorophyll was absent. Metabolism is chemoheterotrophic and obligately aerobic to microaerotolerant. Oxidasepositive. Denitrification, arginine and gelatin hydrolysis, indole production and glucose acidification were negative. Predominant fatty acids are $18: 1 \omega 7 c, 16: 0$ and cyclo 19:0. The $\mathrm{G}+\mathrm{C}$ content of genomic DNA is $67 \cdot 3-71 \cdot 5 \mathrm{~mol} \%$ (by HPLC). Phylogenetically, the genus forms a distinct clade within the order 'Rhodobacterales'. The genus contains two species, Oceanicola granulosus sp. nov. and Oceanicola batsensis sp. nov.

The type species of the genus is Oceanicola granulosus.

\section{Description of Oceanicola granulosus sp. nov.}

Oceanicola granulosus (gra.nu.lo'sus. N.L. masc. adj. granulosus granular).

The description of this species is the same as that for the genus. Cells are $1 \cdot 1-2 \cdot 1 \mu \mathrm{m}$ wide and $0 \cdot 5-1 \cdot 0 \mu \mathrm{m}$ long. Colonies are $0.5-1.0 \mathrm{~mm}$ in diameter, uniformly circular, convex and opaque. Temperature range for growth is $4-40{ }^{\circ} \mathrm{C}$, optimum $28^{\circ} \mathrm{C}$. $\mathrm{pH}$ range for growth is $5 \cdot 5-9 \cdot 5$, optimum $7 \cdot 5-8 \cdot 0$. Grows at $0 \cdot 25-10 \cdot 0 \% \mathrm{NaCl}$. Catalaseand urease-negative. Aesculin- and $\beta$-galactosidase-positive. The sole carbon source utilization patterns for differentiating strains are listed in Table 1 and the text. According to Biolog tests, the following substrates were oxidized by all strains: glycogen, Tween $80, \mathrm{~N}$-acetyl-D-glucosamine, Darabitol, D-cellobiose, D-galactose, gentiobiose, $\alpha$-D-glucose, maltose, sucrose, D-trehalose, xylitol, pyruvic acid methyl ester, acetic acid, citric acid, formic acid, $\alpha$-ketobutyric acid, $\alpha$-ketoglutaric acid, L-lactic acid, propionic acid, L-alanine, L-glutamic acid, L-serine, inosine, uridine and 2,3-butanediol. Predominant fatty acids are 16:0 (12$13 \%), 18: 1 \omega 7 c(55-63 \%)$, methyl $18: 1(8-11 \%)$ and cyclo $19: 0(11-13 \%)$.

DNA G $+\mathrm{C}$ content is $70 \cdot 9-71 \cdot 5 \mathrm{~mol} \%$. Isolated from the western Sargasso Sea, Atlantic Ocean. Type strain is strain ${\text { HTCC } 2516^{\mathrm{T}}}^{(=}$ATCC BAA-861 ${ }^{\mathrm{T}}=$ DSM $15982^{\mathrm{T}}=$ KCTC $\left.12143^{\mathrm{T}}\right)$. Reference strain: HTCC2523.

\section{Description of Oceanicola batsensis sp. nov.}

Oceanicola batsensis (ba.tsen'sis. N.L. masc. adj. batsensis from BATS, an abbreviation for Bermuda Atlantic Timeseries Study site)

The description of this species is the same as the genus described above. Cells are $0 \cdot 7-1 \cdot 6 \mu \mathrm{m}$ wide and $0 \cdot 4-0 \cdot 8 \mu \mathrm{m}$ long. Colonies are $0.7-1.5 \mathrm{~mm}$ in diameter, uniformly circular, convex and opaque. Temperature range for growth is $4-40^{\circ} \mathrm{C}$, optimum $30^{\circ} \mathrm{C}$. $\mathrm{pH}$ range for growth is $6 \cdot 0-9 \cdot 0$, optimum $7 \cdot 5-8 \cdot 0$. Grows at $0 \cdot 75-10 \cdot 0 \%$ $\mathrm{NaCl}$. Catalase- and urease-positive. Aesculin- and $\beta$-galactosidase-negative. The sole carbon source utilization patterns for differentiating strains are listed in Table 1 and the text. According to Biolog tests, the following substrates were oxidized by the species: glycogen, Tween 40 , L-arabinose, D-arabitol, D-galactose, mannitol, D-sorbitol, acetic acid, formic acid, D-galactonic acid lactone, D-gluconic acid, $\alpha$-ketobutyric acid, $\alpha$-ketoglutaric acid, L-lactic acid, malonic acid, propionic acid, D-saccharic acid, L-alanyl-glycine, L-glutamic acid, glycyl-L-glutamic acid, L-serine, threonine, putrescine, 2,3-butanediol and 
Table 3. Differential characteristics of Oceanicola granulosus $\mathrm{HTCC} 516^{\top}$ and Oceanicola batsensis $\mathrm{HTCC}^{2597}{ }^{\top}$ from phylogenetically related type species in the 'Rhodobacterales'

Strains: 1, Oceanicola granulosus HTCC2516 ${ }^{\mathrm{T}}$ (this study); 2, Oceanicola batsensis HTCC2597 ${ }^{\mathrm{T}}$ (this study); 3, Jannaschia helgolandensis DSM $14858^{\mathrm{T}}$ (Wagner-Döbler et al., 2003); 4, Octadecabacter arcticus CIP 106732 ${ }^{\mathrm{T}}$ (Gosink et al., 1997); 5, Staleya guttiformis ATCC BAA-5 ${ }^{\mathrm{T}}$ (Labrenz et al., 2000); 6, Sulfitobacter pontiacus DSM 10014 ${ }^{\mathrm{T}}$ (Sorokin, 1995; Labrenz et al., 2000); 7, Roseobacter litoralis ATCC 49566 ${ }^{\mathrm{T}}$ (Shiba, 1991; Labrenz et al., 1999); 8, Ketogulonicigenium vulgarae DSM 4025 (Urbance et al., 2001); 9, 'Marinosulfonomonas methylotropha' $\mathrm{PSCH}_{4}^{\mathrm{T}}$ (Holmes et al., 1997); 10, Ruegeria atlantica IAM 14463 ${ }^{\mathrm{T}}$ (Rüger \& Höfle, 1992; Uchino et al., 1998); 11, Silicibacter lacuscaerulensis DSM $11314^{\mathrm{T}}$ (Petursdottir \& Kristjansson, 1997; González et al., 2003); 12, Antarctobacter heliothermus DSM 11445 ${ }^{\mathrm{T}}$ (Labrenz et al., 1998); 13, Sagittula stellata DSM $11524^{\mathrm{T}}$ (González et al., 1997). Symbols: V, variable; W, weakly positive; ND, not determined. Colony colour: FY, faint yellow; CR, cream; WH, white; BG, beige; CL, colourless; BR, brown; BY; brownish yellow.

\begin{tabular}{|c|c|c|c|c|c|c|c|c|c|c|c|c|c|}
\hline Characteristic & 1 & 2 & 3 & 4 & 5 & 6 & 7 & 8 & 9 & 10 & 11 & 12 & 13 \\
\hline Rosette formation & - & - & - & - & + & + & - & - & + & + & - & + & + \\
\hline Motility & - & - & - & - & + & + & + & - & - & - & - & $-{ }^{*}$ & - \\
\hline Colony colour & FY & FY & WH & WH & BG & CL & PI & $\mathrm{BR}$ & $\mathrm{CL}$ & BG & $\mathrm{BR}$ & BY & CR \\
\hline Bacteriochlorophyll $a$ & - & - & - & - & $\mathrm{V}$ & - & + & - & - & - & - & - & - \\
\hline Gas vesicles & - & - & - & + & - & - & - & ND & - & ND & + & - & - \\
\hline PHB & + & + & $\mathrm{ND} \dagger$ & - & + & + & - & ND & ND & ND & - & + & + \\
\hline Oxidase & + & + & $\mathrm{W}$ & - & + & + & + & + & + & $\mathrm{ND}$ & + & + & + \\
\hline Catalase & - & + & + & + & $\mathrm{w}$ & + & + & + & + & + & + & + & + \\
\hline Growth at $37^{\circ} \mathrm{C}$ & + & + & - & - & - & - & - & - & + & - & + & + & + \\
\hline Gelatin hydrolysis & - & - & - & - & - & - & + & ND & ND & - & $\mathrm{ND}$ & + & - \\
\hline Nitrate reduction & - & - & - & - & + & ND & - & $\mathrm{ND}$ & + & + & + & + & - \\
\hline \multicolumn{14}{|l|}{ Utilization of: } \\
\hline Glucose & + & - & + & $\mathrm{V}$ & $\mathrm{W}$ & ND & + & + & + & + & - & + & + \\
\hline Fructose & - & - & + & - & $\mathrm{w}$ & ND & ND & + & + & - & ND & + & + \\
\hline Mannitol & - & + & + & ND & - & $\mathrm{ND}$ & ND & + & $\mathrm{ND}$ & + & ND & + & ND \\
\hline Methanol & - & - & ND & - & - & ND & - & ND & + & ND & ND & - & + \\
\hline Succinate & - & - & + & $\mathrm{V}$ & + & $\mathrm{ND}$ & + & + & + & + & ND & + & + \\
\hline Butyrate & - & - & - & - & - & + & - & ND & ND & ND & ND & + & + \\
\hline Citrate & - & - & + & $\mathrm{V}$ & - & $\mathrm{ND}$ & + & ND & + & + & - & + & + \\
\hline \multicolumn{14}{|l|}{ Major fatty acids: } \\
\hline 3-OH 10:0 & $1 \cdot 5$ & $0 \cdot 4$ & $5 \cdot 6$ & 4 & $5 \cdot 9$ & $3 \cdot 6$ & $1 \cdot 9$ & $3 \cdot 6$ & $\mathrm{ND}$ & - & $1 \cdot 6$ & - & - \\
\hline $3-\mathrm{OH} 12: 0$ & $1 \cdot 6$ & - & - & - & - & - & - & $2 \cdot 9$ & ND & $7 \cdot 7$ & $4 \cdot 0$ & - & - \\
\hline 3-OH $14: 1$ & - & - & - & - & $2 \cdot 1$ & $2 \cdot 0$ & $3 \cdot 9$ & - & ND & $1 \cdot 9$ & - & - & - \\
\hline $16: 0$ & $11 \cdot 9$ & $15 \cdot 0$ & - & 6 & $3 \cdot 9$ & $8 \cdot 1$ & $1 \cdot 1$ & $33 \cdot 5$ & ND & - & $1 \cdot 6$ & $2 \cdot 5$ & $8 \cdot 6$ \\
\hline $16: 1 \omega 7 c$ & - & - & - & 8 & - & $1 \cdot 2$ & - & - & ND & - & $0 \cdot 3$ & $0 \cdot 8$ & - \\
\hline $18: 0$ & $0 \cdot 9$ & $2 \cdot 4$ & $10 \cdot 8$ & - & $0 \cdot 7$ & - & $1 \cdot 3$ & $2 \cdot 9$ & ND & - & $2 \cdot 6$ & $1 \cdot 0$ & $6 \cdot 8$ \\
\hline $18: 1 \omega 7 c$ & $62 \cdot 8$ & $31 \cdot 0$ & $45 \cdot 1$ & $75 \ddagger$ & $79 \cdot 7$ & $79 \cdot 1$ & $88 \cdot 8$ & $52 \ddagger$ & ND & 80 & $81 \cdot 7$ & $83 \cdot 2$ & $\S$ \\
\hline methyl $18: 1$ & $8 \cdot 1$ & - & $5 \cdot 7$ & - & - & - & - & - & ND & - & $2 \cdot 2$ & - & - \\
\hline cyclo 19:0 & $10 \cdot 8$ & $40 \cdot 4$ & $25 \cdot 1$ & - & - & - & - & - & ND & - & - & $2 \cdot 4$ & $1 \cdot 8$ \\
\hline $\mathrm{G}+\mathrm{C}$ content $(\mathrm{mol} \%)$ & 72 & 67 & 63 & 57 & 55 & 62 & 57 & 54 & 57 & 55 & 66 & 62 & 65 \\
\hline
\end{tabular}

${ }^{\star}$ Three strains of the species showed motility.

$\dagger$ Inclusion bodies were found in the cells.

$\ddagger 18: 1 \omega 7 c+18: 1 \omega 9 t+18: 1 \omega 12 t$.

$\$$ Major fatty acid, but not quantified.

DL- $\alpha$-glycerol phosphate. Predominant fatty acids are 16:0 $(15 \%), 18: 1 \omega 7 c(31 \%)$ and cyclo 19:0 (40\%).

DNA $\mathrm{G}+\mathrm{C}$ content is $67.3 \mathrm{~mol} \%$. Isolated from the western Sargasso Sea, Atlantic Ocean. Type strain is strain HTCC $2597^{\mathrm{T}}\left(=\right.$ ATCC BAA- $863^{\mathrm{T}}=\mathrm{DSM} 15984^{\mathrm{T}}=\mathrm{KCTC}$ $\left.12145^{\mathrm{T}}\right)$.

\section{ACKNOWLEDGEMENTS}

We would like to thank Dr J. Euzéby for his recommendations about etymology. We are grateful to crews of the RV Weatherbird II for helping us collect sea water samples. We are also grateful to K. Vergin and R. Morris for their helpful suggestions regarding the manuscript. This study was supported by grants from Diversa Corp. and the National Science Foundation grant DEB-0207085. 


\section{REFERENCES}

Allgaier, M., Uphoff, H., Felske, A. \& Wagner-Döbler, I. (2003). Aerobic anoxygenic photosynthesis in Roseobacter clade bacteria from diverse marine habitats. Appl Environ Microbiol 69, 5051-5059.

Buchan, A., Collier, L. S., Neidle, E. L. \& Moran, M. A. (2000). Key aromatic-ring-cleaving enzyme, protocatechuate 3,4-dioxygenase, in the ecologically important marine Roseobacter lineage. Appl Environ Microbiol 66, 4662-4672.

Cho, J.-C. \& Giovannoni, S. J. (2003a). Croceibacter atlanticus gen. nov., sp. nov., a novel marine bacterium in the family Flavobacteriaceae. Syst Appl Microbiol 26, 76-83.

Cho, J.-C. \& Giovannoni, S. J. (2003b). Parvularcula bermudensis gen. nov., sp. nov., a marine bacterium that forms a deep branch in the $\alpha$-Proteobacteria. Int J Syst Evol Microbiol 53, 1031-1036.

Connon, S. A. \& Giovannoni, S. J. (2002). High-throughput methods for culturing microorganisms in very-low-nutrient media yield diverse new marine isolates. Appl Environ Microbiol 68, 3878-3885.

Doronina, N. V., Trotsenko, Y. A. \& Tourova, T. P. (2000). Methylarcula marina gen. nov., sp. nov. and Methylarcula terricola sp. nov.: novel aerobic, moderately halophilic, facultatively methylotrophic bacteria from coastal saline environments. Int J Syst Evol Microbiol 50, 1849-1859.

Garrity, G. M. \& Holt, J. G. (2001). The road map to the manual. In Bergey's Manual of Systematic Bacteriology, pp. 119-166. Edited by G. M. Garrity. New York: Springer.

Giovannoni, S. \& Rappé, M. (2000). Evolution, diversity and molecular ecology of marine prokaryotes. In Microbial Ecology of the Oceans, pp. 47-84. Edited by D. L. Kirchman. New York: Wiley.

González, J. M., Mayer, F., Moran, M. A., Hodson, R. E. \& Whitman, W. B. (1997). Sagittula stellata gen. nov., sp. nov., a lignintransforming bacterium from a coastal environment. Int J Syst Bacteriol 47, 773-780.

González, J. M., Simó, R., Massana, R., Covert, J. S., Casamayor, E. O., Pedrós-Alió, C. \& Moran, M. A. (2000). Bacterial community structure associated with a dimethylsulfoniopropionate-producing North Atlantic algal bloom. Appl Environ Microbiol 66, 4237-4246.

González, J. M., Covert, J. S., Whitman, W. B. \& 8 other authors (2003). Silicibacter pomeroyi sp. nov. and Roseovarius nubinhibens sp. nov., dimethylsulfoniopropionate-demethylating bacteria from marine environments. Int J Syst Evol Microbiol 53, 1261-1269.

Gosink, J. J., Herwig, R. P. \& Staley, J. T. (1997). Octadecabacter arcticus gen. nov., sp. nov., and $O$. antarcticus, sp. nov., nonpigmented, psychrophilic gas vacuolate bacteria from polar sea ice and water. Syst Appl Microbiol 20, 356-365.

Holmes, A. J., Kelly, D. P., Baker, S. C., Thompson, A. S., De Marco, P., Kenna, E. M. \& Murrell, J. C. (1997). Methylosulfonomonas methylovora gen. nov., sp. nov., and Marinosulfonomonas methylotropha gen. nov., sp. nov. novel methylotrophs able to grow on methanesulfonic acid. Arch Microbiol 167, 46-53.

Jukes, T. H. \& Cantor, C. R. (1969). Evolution of protein molecules. In Mammalian Protein Metabolism, pp. 21-132. Edited by H. N. Munro. New York: Academic Press.

Labrenz, M., Collins, M. D., Lawson, P. A., Tindall, B. J., Braker, G. \& Hirsch, P. (1998). Antarctobacter heliothermus gen. nov., sp. nov., a budding bacterium from hypersaline and heliothermal Ekho Lake. Int J Syst Bacteriol 48, 1363-1372.

Labrenz, M., Collins, M. D., Lawson, P. A., Tindall, B. J., Schumann, P. \& Hirsch, P. (1999). Roseovarius tolerans gen. nov., sp. nov., a budding bacterium with variable bacteriochlorophyll a production from hypersaline Ekho Lake. Int J Syst Bacteriol 49, 137-147.
Labrenz, M., Tindall, B. J., Lawson, P. A., Collins, M. D., Schumann, P. \& Hirsch, P. (2000). Staleya guttiformis gen. nov., sp. nov. and Sulfitobacter brevis sp. nov., $\alpha$-3-Proteobacteria from hypersaline, heliothermal and meromictic antarctic Ekho Lake. Int J Syst Evol Microbiol 50, 303-313.

Lafay, B., Ruimy, R., Rausch de Traubenberg, C., Breittmayer, V., Gauthier, M. J. \& Christen, R. (1995). Roseobacter algicola sp. nov., a new marine bacterium isolated from the phycosphere of the toxinproducing dinoflagellate Prorocentrum lima. Int J Syst Bacteriol 45, 290-296.

Ledyard, K. M., DeLong, E. F. \& Dacey, J. W. H. (1993). Characterization of a DMSP-degrading bacterial isolate from the Sargasso Sea. Arch Microbiol 160, 312-318.

Ludwig, W., Strunk, O., Klugbauer, S., Klugbauer, N., Weizenegger, M., Neumaier, J., Bachleitner, M. \& Schleifer, K. H. (1998). Bacterial phylogeny based on comparative sequence analysis. Electrophoresis 19, 554-568.

Mesbah, M., Premachandran, U. \& Whitman, W. B. (1989). Precise measurement of the $\mathrm{G}+\mathrm{C}$ content of deoxyribonucleic acid by high-performance liquid chromatography. Int J Syst Bacteriol 39, 159-167.

Petursdottir, S. K. \& Kristjansson, J. K. (1997). Silicibacter lacuscaerulensis gen. nov., sp. nov., a mesophilic moderately halophilic bacterium characteristic of the Blue Lagoon geothermal lake in Iceland. Extremophiles 1, 94-99.

Porter, K. G. \& Feig, Y. S. (1980). The use of DAPI for identifying and counting aquatic microflora. Limnol Oceanogr 25, 943-948.

Pukall, R., Buntefuß, D., Frühling, A., Rohde, M., Kroppenstedt, R. M., Burghardt, J., Lebaron, P., Bernard, L. \& Stackebrandt, E. (1999). Sulfitobater mediterraneus sp. nov., a new sulfite-oxidizing member of the $\alpha$-Proteobacteria. Int J Syst Bacteriol 49, 513-519.

Rappé, M. S., Vergin, K. \& Giovannoni, S. J. (2000). Phylogenetic comparisons of a coastal bacterioplankton community with its counterparts in open ocean and freshwater systems. FEMS Microbiol Ecol 33, 219-232.

Rüger, H.-J. \& Höfle, M. G. (1992). Marine star-shaped-aggregateforming bacteria: Agrobacterium atlanticum sp. nov.; Agrobacterium metiori sp. nov.; Agrobacterium ferrugineum sp. nov., nom. rev.; Agrobacterium gelatinovorum sp. nov., nom. rev.; and Agrobacterium stellulatum sp. nov., nom. rev. Int J Syst Bacteriol 42, 133-143.

Schaefer, J. K., Goodwin, K. D., McDonald, I. R., Murrell, J. C. \& Oremland, R. S. (2002). Leisingera methylohalidivorans gen. nov., sp. nov., a marine methylotroph that grows on methyl bromide. Int J Syst Evol Microbiol 52, 851-859.

Shiba, T. (1991). Roseobacter litoralis gen. nov., sp. nov., and Roseobacter denitrificans sp. nov., aerobic pink-pigmented bacteria which contain bacteriochlorophyll a. Syst Appl Microbiol 14, 140-145.

Smibert, R. M. \& Krieg, N. R. (1994). Phenotypic characterization. In Methods for General and Molecular Microbiol, pp. 611-654. Edited by P. Gerhardt, R. G. E. Murray, W. A. Wood \& N. R. Krieg. Washington, DC: American Society for Microbiology.

Sorokin, D. Y. (1995). Sulfitobacter pontiacus gen. nov., sp. nov., a new heterotrophic bacterium from the Black Sea, specialized on sulfite oxidation. Microbiology (English translation of Mikrobiologiya) 64, 295-305.

Stackebrandt, E. \& Göbel, B. M. (1994). Taxonomic note: a place for DNA-DNA reassociation and 16S rRNA sequence analysis in the present species definition in bacteriology. Int $J$ Syst Bacteriol 44, 846-849.

Stackebrandt, E. \& Liesack, W. (1993). Nucleic acids and classification. In Handbook of New Bacterial Systematics. Edited by M. Goodfellow \& A. G. O’Donnell. London: Academic Press. 
Suzuki, T., Muroga, Y., Takahama, M. \& Nishimura, Y. (1999). Roseivivax halodurans gen. nov., sp. nov. and Roseivivax halotolerans sp. nov., aerobic bacteriochlorophyll-containing bacteria isolated from a saline lake. Int J Syst Bacteriol 49, 629-634.

Swofford, D. (2002). PAUP*. Phylogenetic Analysis Using Parsimony ( ${ }^{*}$ and Other Methods). Sunderland, MA: Sinauer Associates.

Uchino, Y., Hirata, A., Yokota, A. \& Sugiyama, J. (1998). Reclassification of marine Agrobacterium species: proposals of Stappia stellulata gen. nov., comb. nov., Stappia aggregata sp. nov., nom. rev., Ruegeria atlantica gen. nov., comb. nov., Ruegeria gelatinovora comb. nov., Ruegeria algicola comb. nov., and Ahrensia kieliense gen. nov., sp. nov., nom. rev. J Gen Appl Microbiol 44, 201-210.

Urbance, J. W., Bratina, B. J., Stoddard, S. F. \& Schmidt, T. M. (2001). Taxonomic characterization of Ketogulonigenium vulgare gen. nov., sp. nov. and Ketogulonigenium robustum sp. nov., which oxidize L-sorbose to 2-keto-L-gulonic acid. Int J Syst Evol Microbiol 51, 1059-1070.

Wagner-Döbler, I., Rheims, H., Felske, A., Pukall, R. \& Tindall, B. J. (2003). Jannaschia helgolandensis gen. nov., sp. nov., a novel abundant member of the marine Roseobacter clade from the North Sea. Int J Syst Evol Microbiol 53, 731-738.

Wayne, L. G., Brenner, D. J., Colwell, R. R. \& 9 other authors (1987), International Committee on Systematic Bacteriology. Report of the ad hoc committee on reconciliation of approaches to bacterial systematics. Int J Syst Bacteriol 37, 463-464.

Zengler, K., Toledo, G., Rappé, M. S., Elkins, J., Mathur, E. J., Short, J. M. \& Keller, M. (2002). Cultivating the uncultured. Proc Natl Acad Sci U S A 99, 15681-15686. 